Revista Iberoamericana, Vol. LXVIII, Núm. 199, Abril-Junio 2002, 441-457

\title{
TELÉMACO EN AMÉRICA LATINA NOTAS SOBRE LA BÚSQUEDA DEL PADRE EN CINE Y LITERATURA
}

\author{
POR \\ JORGE RUFFINELLI \\ Stanford University
}

La búsqueda se ha convertido en un tema fundamental de la literatura y el cine de América Latina, especialmente en los años noventa del siglo pasado. Búsquedas (Santo Grial, Vida Eterna, lugares sacros y míticos) que implican, diría Joseph Campbell, el traslado físico y geográfico del "héroe” (hombre o mujer) por lugares remotos y cumpliendo algunas "tareas” o superando algunos “obstáculos” que se interponen entre el protagonista y su meta. Y también búsquedas de personas (¿desaparecidas?) que fueron alguna vez significativas en la vida de ese protagonista, y que al presente, por su ausencia, lo han dejado huérfano de sentido, perdido en su universo.

¿Tiene este fenómeno alguna relación con el fin / comienzo del milenio? La respuesta es probablemente positiva. El peregrino que se lanza al camino (de la imaginación) y se cruza con decenas de otros peregrinos, cumple un rito que no le es estrictamente personal, aunque personalmente así lo viva. El cambio de siglo y milenio tuvo una inmensa fuerza en el imaginario del cine. Es notable en él la idea del "fin del mundo," tomando ese término en su significado tanto geográfico como temporal. "Fin del mundo” es la imagen seductora y terrible de un lugar tan lejano a nosotros que su descubrimiento sorprende porque creíamos que todo estaba ya visto y descubierto. También implica un acabamiento terminal o apocalíptico. El Apocalipsis es un final que da paso a otro comienzo. Y nuestro nuevo milenio se inicia con ansiedades de guerras santas, de conversiones, de búsquedas espirituales en un mundo tecnificado y materialista.

LA(s) BÚSQUEDA(s)

Si hiciéramos un rápido repaso por el cine de los años noventa, encontraríamos un asombroso conjunto de películas de "búsqueda”. La búsqueda del padre —una de las más importantes - coincide con otras, no las desplaza. Se destaca en el conjunto pero son diversas las figuraciones que encarnan las incertidumbres de esta época. En este sentido, Eliseo Subiela se adelanta: ya en 1980, Pablo busca a su padre en el Chaco, en La conquista del paraíso (Eliseo Subiela, Argentina);

Martín Nunca parte de la Patagonia y llega a México buscando a su padre, en El viaje (Fernando Solanas, Argentina 1992); 
Erasmo y Saúl buscan al padre en Un crisantemo estalla en cinco esquinas (Daniel Burman, Argentina 1996);

João busca al padre en el Nordeste, en Central do Brasil (Walter Salles, Brasil 1997); Rosalía busca a su padre en el Norte, en Pequeños milagros (Eliseo Subiela, Argentina 1997);

Yuliett encuentra a su padre sin buscarlo y Fabiola lo busca sin encontrarlo, en ¿Quién diablos es Juliette? (Carlos Marcovich, México 1997);

Martín Hache va a Madrid en busca de su padre — famoso director de cine- en Martín hache (Adolfo Aristarain, Argentina 1997).

Manuel busca a su padre en la Patagonia, en El camino (Javier Olivera, Argentina 2000); Rufino decide huir de la ciudad de México pero antes busca a su padre, a quien no conoce, en De la calle (Gerardo Tort, México 2001).

Esperanza va al Norte y llega hasta Los Angeles, buscando a su hija, en Santitos (Alejandro Springall, México 1999);

Damián (en viaje inverso al de Esperanza) sale de Los Angeles y llega al extremo sur de Baja California para cumplir una promesa ante la tumba de su abuela y a la vez sufrir una expiación, en Bajo California (Carlos Bolado, México 1998);

Rocco y Rodrigo se van a Acapulco a cumplir una promesa con las cenizas del abuelo, en Por la libre (Juan Carlos De Llaca, México 2000);

Julia busca en Veracruz a su compañero de baile en Danzón (María Novaro, México 1991);

Los personajes de Invierno, mala vida (Gregorio Cramer, Argentina 1997), en cambio, no necesitan viajar a la Patagonia: ya están en ella, y el viaje fue hecho por sus antepasados.

El desiderátum de estas búsquedas es un gran cambio — una transformación — de los paradigmas a través de los cuales se ha desarrollado y cumplido el imaginario político de fines de siglo. Si el padre (u otras figuras familiares) “desaparecido” puede encarnar en el cine argentino la tragedia individual y nacional de los “desaparecidos” (que en la práctica política cotidiana dio origen a Madres de la Plaza de Mayo, a las Abuelas y actualmente a H.I.J.O.S.), no siempre los símbolos funcionan con la inmediatez del realismo.

Véase el caso chileno, tan demostrativo. En la década anterior, el personaje de Imagen latente (Pablo Perelman, Chile 1987) buscaba los rastros de su hermano desaparecido y se atrevía a pasar frente a Villa Grimaldi — célebre centro de detención y torturas—, e incluso fotografiar su entrada, velozmente, desde su coche en marcha. No era una búsqueda literal, él sabía que su hermano había muerto, del mismo modo que Perelman lo sabía de su propio hermano — razón de ser de su película. El film es visualmente impactante y juega con la condición de fotógrafo de Pedro y su mujer, y su propio título alude a la sobreexposición de luz que provoca una imagen "latente” y no nítida. Pudo haber sido un documento directo de denuncia, pero es eso y algo más sutil y profundo: la exploración de una herida psicológica, emocional e intelectual que no cicatriza así pasen los años y en la que se han formado ya algunas generaciones. De este modo, Perelman llevó al presente los sucesos del pasado, reflexionó sobre la "naturaleza” del presente, el pasado y el futuro, y no los dejó morir ni desaparecer.

Muy poco antes que Imagen latente, La estación del regreso (Leonardo Kocking, Chile 1987) contó la historia de Paula, quien busca tenazmente a su compañero secuestrado 
una noche de su propio domicilio. Kocking “desideologiza” el tema: Paula prescinde del discurso del compromiso, no parte de solidaridades de grupo y emprende la búsqueda ella sola; tampoco se sabe mucho sobre las actividades políticas de Carlos antes de su detención. Laura se demuestra como uno de esos tenaces personajes femeninos a quienes la literatura de William Faulkner nos acostumbró. La suya es una “odisea” femenina: Penélope abandona la rueca y sale al mundo.

En estas dos películas valientes (pues fueron realizadas durante la dictadura) el viaje y la búsqueda son su propio referente, no necesitan simbolismos. Sus personajes saben lo que quieren —o pronto lo aprenden-, así como los riesgos de su empresa. Aún faltarían algunos años para que el viaje y la búsqueda comenzaran a simbolizarse como motivos.

Y lo hicieron durante los años noventa porque estos fueron la triple víspera del fin de la década, el siglo y el milenio. Se enfrentaron a la teoría del "fin de la historia” y la destrucción de los absolutos y las metanarrativas, y con ello asumieron la inquietud y la angustia. La certeza del fin de una época selló su imaginario. En fugaz comparación con otra época anterior, recordemos cómo hacia 1910, en vísperas del pasaje del cometa Halley, se hablaba en Argentina (feminizando el artículo) de "la fin del mundo" (Parisi y González). Era el sentimiento del momento: un fin que sólo encontraba el miedo para expresarse. Ese miedo provocó ingenuos “observatorios” caseros, confesiones, arrepentimientos, bunkers bajo tierra, y varios desdichados suicidios. Siete décadas y media más tarde (1986), otra vez el Cometa Halley pasó visible para la Tierra pero ahora coincidió con el cambio de milenio, multiplicando desde el cielo la idea (y sus sensaciones) de final y acabamiento. La desazón corrió por las venas de América Latina. ¿Que volverá a suceder en 2062 ?

Observemos más de cerca el tema del “milenio”, con su inquietud expresada en el imaginario con los dos sentidos indicados —el espacial y el temporal— dentro del nuevo cine latinoamericano. Comparemos por un momento los inicios o planteos de dos películas notables, una brasileña y argentina la otra: Terra estrangeira (Walter Salles y Daniela Thomas, Brasil 1995) y Esperando al Mesías (Daniel Burman, Argentina 2000). En la primera, en São Paulo, los “idus" de marzo de 1990 constituyen una fecha "histórica" porque resultaron el momento en que el flamante gobierno de Fernando Collor de Melo inició el desastre económico, congelando las cuentas de los pequeños ahorristas, desbarrancó a Brasil en el caos y provocó una notable emigración por causas económicas. Manuela, la humilde costurera de origen vasco y madre del joven Paco, que juntó en el banco los ahorros de una vida para regresar, ya viuda, a la tierra de su padre, ve sorprendida en la televisión el anuncio de la noticia fatal para sus sueños, su corazón no resiste y en un síncope muere.

El comienzo de Esperando al Mesías: tomas televisivas sobre una crisis inesperada en el Sudeste Asiático, cuando el "Banco de Oriente” quiebra dejando — en palabras de una locutora-, un "tendal de víctimas entre los ahorristas" y los inversores de varios países. Este es el envión inicial de su historia.

En ambos casos, la mejor comparación posible es con el estallido de una bomba en las dos ciudades latinoamericanas, São Paulo y Buenos Aires. Las dos películas toman pie en ese planteo u origen y sus relatos narran a partir del mismo lo que les va a suceder a sus personajes “el día después” (o los “días después”) del desastre financiero. En el caso de 
Terra estrangeira, muerta la madre será el hijo quien intente llegar a la tierra del abuelo. En Esperando al Mesías a las primeras tomas sobre las bolsas de Tokyo, Frankfurt, New York y Buenos Aires —que consiguen insertarnos en la "globalidad" económica contemporánea-, les suceden más tarde unas historias concretas, las vidas paralelas de un joven judío que se rebela ante el determinismo cultural de su futuro personal (que él llama el Plan y no es otra cosa que la cultura endogámica judía), y la de Santamaría, un bancario a quien cesan en su trabajo y a quien su mujer echa de casa con la misma indiferencia con que los empresarios lo despiden.

Estas dos películas se convierten en paradigmas de este cine latinoamericano porque los espectadores tenemos un punto de identidad con ellas: las crisis financieras y económicas, la deuda externa, la sangría del servicio de la deuda, la esclavitud frente al FMI, el BID y el resto de la banca internacional.

Y este es un punto de partida importante del nuevo cine. Su capacidad de producir el "shock del reconocimiento". La sensación colectiva de que "algo" se ha derrumbado definitivamente. Esta sensación viene desde mediados de los noventa y no funciona necesariamente como respuesta documental a problemas económicos de la región o del mundo. Anclan en ellos, se afirman en circunstancias que afectan a todos, pero de lo que estas películas están hablando es de otra cosa que provisoriamente llamaríamos la desaparición de la utopía y la ansiedad por la llegada del milenio.

Confesión de parte. El mismo Daniel Burman, dijo en una entrevista a propósito de Esperando al Mesías:

Yo comencé a concebir la idea de filmar esta película, cuando el mundo, o al menos mi país, estaba en plena efervescencia [con] el tema del fin del milenio. Y en muchos lugares se comenzó a hablar de la llegada del Mesías, como dicen las escrituras, y han profetizado diferentes personas. Pero a mí se me ocurrió que el Mesías podía ser la persona que se tiene al lado. Hombre, mujer o niño, pero que con una mirada, una sonrisa, un detalle, te hace la vida mejor. De hecho quise decir que hay muchos pequeños Mesías, y que la gente [en cambio] se pasa esperando al gran Mesías. ${ }^{1}$

Es importante subrayar este empequeñecimiento simbólico del proyecto mítico, que ancla en realidades breves, cotidianas e individuales. Son rasgos de la posmodernidad: su pulverización de la utopía, su recurso al minimalismo y a la subjetividad. En una de las películas más deslumbrantes del nuevo cine argentino, Picado fino (Esteban Sapir 1996), se encuentra la síntesis de una mirada sobre una "modernidad" convertida en cajón de deshechos, donde el propio armaggedon — producto del temor atómico y el armamentismo de la guerra fría - se transforma en un temor primitivo por un simple fenómeno de la naturaleza.

La película se destaca visualmente al emplear un conjunto heterogéneo de signos de la vida cotidiana. "Game over", "Round II”, BA — Buenos Aires, que se trueca en BAR"Insert Coin” (¿coito?) y muchas otras referencias similares se reiteran en la pantalla hasta hacer de ésta una película semiótica, repleta de signos para descifrar sin pausa. Pero lo más

1 “Esperando al Mesías, una película argentina sobre la identidad y los judíos”, Zero - Variedades 347, 25 de noviembre de 2000. 
interesante es que su historia es simple y vulgar: una familia disfuncional y unos adolescentes marginales sin futuro. Sin embargo, lo que podría haber dado paso a un melodrama clásico, se desenvuelve como un ejercicio sofisticado de recursos expresivos, entre los cuales se incluyen los del propio cine, por ejemplo, la capacidad del montaje para poner en boca de una maestra discursos de Hitler.

Uno de los personajes introduce expresamente la idea del fin y lo hace en los términos que le corresponden — vulgares y cotidianos, doxa domesticada por el lugar común: “Como están las cosas, parece que el mundo va a reventar”. Sin embargo, coherente en esta caída de las metanarrativas modernas al minimalismo posmoderno, la destrucción global se trueca en un simple "eclipse” de sol. A eso hemos sido reducidos, irónicamente. Nuestra realidad ha llegado a ser tan insignificante que el apocalíptico “fin del mundo” está señalado simbólicamente por un eclipse común. Nuestro drama sublime se hizo irrisoria e insignificante comedia.

EL FIN DE LA UTOPÍA

¿Qué pudo haber sucedido para que se llegase a estas auto-percepciones irónicas, nihilistas, auto-flagelantes? ¿Qué fue lo que se quebró para producir esa ansiedad? Lo que se derrumbó fue la utopía.

La utopía duró varios años. En los sesenta generó la cultura de resistencia (la “estética del hambre” de Glauber Rocha, el cine-liberación de Solanas y Getino, el cine-junto-alpueblo de Sanjinés, el cine “imperfecto” de García Espinosa, los manifiestos anarcos de Birri), la canción-protesta, el activismo político de los jóvenes en pos de un mundo mejor. Al mismo tiempo, la represión canceló sueños: la masacre de la Plaza de las Tres Culturas en México, las dictaduras militares en el Cono Sur y Brasil, la multiplicación de bayonetas en todo el continente. El golpe de gracia fue luego la caída del marxismo. ¿Es que ya no iba a poder ayudarnos a entender el mundo? ¿Quedaríamos a merced de las transnacionales y de una “economía de mercado” también llamada, con inspiración metafórica, “capitalismo salvaje”?

El nuevo cine del milenio comenzó por no dar respuestas generales, que se creyeran válidas para todo habitante, desde la Patagonia hasta el Río Grande. Aprendió desde la cuna que no existen verdades absolutas, pero tampoco se refugió en el relativismo. Las respuestas tomaron la forma de preguntas: las preguntas de imágenes, las imágenes de diversos “viajes” de descubrimiento. Si alguna vez Colón llegó — por error- a estas playas, ahora eran los latinoamericanos quienes realizaban el viaje iniciático, de descubrimiento y (relativa, mínima) conquista. Una expresión de ello fueron las "películas del camino", las historias de personajes que salen a buscar. O a huir. Se le llaman road movies porque ese género en los Estados Unidos describe largos viajes sin otro propósito que el viaje mismo. Habría que buscarle otro nombre al cine de viajes en América Latina para relacionar la búsqueda del padre en el Nordeste de Central do Brasil con la entrega de la estatua de la Virgen a un narcotraficante católico atravesando las montañas de Bolivia en Cuestión de fe (Marcos Loayza, Bolivia 1995).

En el cine argentino esa búsqueda/peregrinación correspondió al viaje desde Buenos Aires a la Patagonia. En el cine de Brasil fue el viaje al Nordeste, pero fuese la Patagonia 
o el Nordeste, en todo caso se trataba de lugares distantes de los “centros” metropolitanos $y$, por ende, lugares que parecen estar en el "fin del mundo". Porque el sentimiento milenarista de fin y reinicio no es sólo temporal, sino también geográfico, como señalé antes.

Para el imaginario argentino, el viaje encontró a mediados de los ochenta una de las mejores metáforas de la disolución y el deterioro en la fabulosa historia de un equipo que va a filmar La película del Rey (Carlos Sorín, Argentina 1985) en la Patagonia. Históricamente, el rey había sido Orellie Antoine de Tounens, y su empresa demencial la de autoproclamarse Rey de la Araucanía y la Patagonia. Sin embargo, el tema histórico paulatinamente es desplazado por el de la filmación misma, que es la de un gran deterioro, un fracaso sin fin. El equipo de filmación entra en crisis cuando su financiamiento se agota, muchos actores y técnicos se vuelven a Buenos Aires abandonando el proyecto que, sin embargo, director e intérprete se empecinan en continuar al punto de sustituir a los extras con patéticos y surrealistas monigotes plantados en el desierto.

Creo que esta impecable película de Sorín fue pionera porque contribuyó a descubrir un territorio fantasmagórico que estaba en el mítico "fin del mundo" —aunque ya incluso peregrinos más lejanos, como el mexicano Emilio Fernández y su fotógrafo Gabriel Figueroa, lo habían explorado en 1955 con el melodrama rural La Tierra del Fuego se apaga (Argentina).

A comienzos de los noventa Fernando E. Solanas hizo iniciar en esa misma latitud austral el viaje de reconocimiento e iniciación de su Martín Nunca por América Latina en El Viaje (Argentina 1992). Para Solanas — y en general para sus compatriotas argentinos el “viaje” implicó entonces, significativamente, un encuentro con las raíces del continente, con su diversidad espléndida, dolorosa y trágica, después de tantas décadas de vivir de espaldas, en la protección de un pretendido “europeísmo”.

La noción de que el fin del mundo es tan geográfico como temporal fue siempre clara para Walter Salles y Daniela Thomas. En Terra estrangeira — película con la que comencé este ensayo- la joven Alex le indica a Paco el sinfín del horizonte marítimo (ellos se encuentran en Portugal) y añade: “Tú no tienes idea de donde estás, ¿¿verdad? Esto aquí es la punta de Europa. [Ella abre los brazos]. ¡Esto aquí es el fin! (Thomas, Bernstein y Salles 67).

A su vez, en Central do Brasil, cuando Dora y João llegan al Nordeste, un comerciante local comenta: "Esto aquí es el fin del mundo, doña...” (Carneiro, Bernstein y Salles 90).

No hay entonces por dónde escapar; sea en la Patagonia argentina, en Portugal o en el Nordeste brasileño, los personajes se enfrentan al "fin del mundo".

"Vine a Comala PORQue ..."

En la literatura latinoamericana existen pocos ejemplos más elocuentes de ese “viaje” al "fin del mundo" y en "búsqueda del padre," que Pedro Páramo (Juan Rulfo 1955). "Vine a Comala porque me dijeron que aquí vivía un tal Pedro Páramo. Mi madre me lo dijo. Y yo le prometí que vendría a verlo en cuanto ella muriera. Le apreté sus manos en señal de que lo haría; pues ella estaba por morirse y yo en un plan de prometerlo todo” 
(109). En ese comienzo de la novela se sintetiza la tríada familiar: desde su lecho de muerte la madre abandonada envía al hijo en busca del padre. Para Juan Preciado — tan despreciado como su madre en el abandono-, el padre genera curiosas sensaciones: "comencé a llenarme de sueños, a darle vuelo a las ilusiones. Y de ese modo se me fue formando un mundo alrededor de la esperanza que era aquel señor llamado Pedro Páramo" (109).

La que emprende Preciado es una Telemaquia, una búsqueda del padre por los infiernos del calor, la desesperanza, el pecado, los susurros adheridos a las paredes y, finalmente, la muerte. Desde su aparición a mediados de los años cicuenta, Pedro Páramo pronto se convirtió en uno de los libros más admirados de la literatura continental. Por debajo y en secreto, en el imaginario mexicano, difundió su influencia generativa como si fuese uno de esos ríos subterráneos del desierto cuya existencia sólo las vegetaciones espaciadas del suelo permiten sospechar.

En 2001, Federico Campbell publicó La clave Morse, un libro expresamente inspirado en Juan Rulfo (el acápite de Pedro Páramo lo inicia), cuyo tema y razón de ser es la recuperación e invención del padre a través de la memoria. Libro “desvergonzadamente autobiográfico", ${ }^{2}$ fue iniciado a comienzos de los noventa pero Campbell no lo concluyó hasta que se agotó la década, el siglo y el milenio. ${ }^{3}$

El libro va más allá de la búsqueda "sentimental”. Al contrario, se despoja de lo más obvio y previsible de la escritura memoriosa — el pecado de la auto-compasión por la pérdida sufrida-, y se articula como el hallazgo de la continuidad identitaria, que nos habla de historia y a la vez de simultaneidad. Esa continuidad simultánea — esa simultaneidad histórica - surge de la coincidencia peculiar, metafórica y estilística de los oficios: el padre telegrafista y el hijo periodista se superponen y acaban siendo el mismo. En ese sentido, La clave Morse es la "clave” de la escritura. El relato de Campbell está escrito con tal desnudez despojada de literariedad, con tal pureza de escritura renuente a poetizar y “emocionar”, que podría describírselo como “telegráfico”. Él, como su padre, dedicó la vida a la comunicación y su instrumento de práctica cotidiana (la máquina de escribir)

\footnotetext{
${ }^{2}$ Carta de Campbell al autor de este artículo.

${ }^{3}$ Este libro cuenta con una versión anterior, y "primitiva", titulada De cuerpo entero (México: UNAM/Corunda, 1990). Ese fue el nombre genérico de la colección para la que quince escritores mexicanos elaboraron, cada uno, un texto de corte autobiográfico, de modo que cada libro se titula de igual manera aunque los autores sean diferentes. El de Campbell sirvió de base a su libro de 2001, con diferencias sustanciales y curiosas. Por ejemplo, las "hermanas" en De cuerpo entero se llaman Sarina y Silvia; el relato no reflexiona sobre las relaciones ambiguas e informes de la memoria y la ficción. Y en sus últimas quince páginas "imagina” los pensamientos de su hermana Silvia mientras ella se baña en una tina. Reescrita para La clave Morse, esos pensamientos se convierten en un relato de ella y dirigido a su hermano, el escritor. Lo más interesante en De cuerpo entero es la ausencia de cualquier referencia a Rulfo, lo cual permite pensar que en los diez años transcurridos hasta $L a$ clave Morse, y en su reescritura, la figura del padre biológico dejó paso a la aparición poderosa de los "padres literarios." A diferencia de De cuerpo entero, que es casi puramente factual, La clave Morse es una reflexión profunda sobre la memoria y la escritura. La "lección" de los padres literarios, asumida por Campbell, fue la de cultivar un estilo lacónico, "anti-literario", depurado de ornato. Gracias a esa reflexión escritural, en La clave Morse, Campbell consiguió producir la vinculación entre ese estilo y el ejercicio telegráfico (paterno) y periodístico (el suyo).
} 
resultó por ser tan obsoleto como el telégrafo del pasado —-máquinas hoy en el museo de la modernidad que la posmodernidad dejó atrás. ¿Coincidencia es simultaneidad? ¿Es negación de la historia? ¿El hijo es el Padre, como decía Wordsworth? ¿Y acaso el padre es otra cosa que su hijo?

Tradicionalmente, la búsqueda del padre por el hijo ha implicado la intención de éste por capturar su identidad del origen y, en consecuencia, una certidumbre a partir de la cual tomar fuerza para continuar viviendo y dar sentido a la vida. En consecuencia, la desaparición (y a veces la muerte) del padre es una expresión del “fin del mundo", la indicación inequívoca de que la figura mítica también perece. De modo que el viaje de recuperación a través de la memoria intenta, por un lado, darle sentido a esa pérdida con la noción de la mortalidad; pero, por otra, contradictoriamente, intenta revivir lo que ha acabado. Movimientos contrarios, sístole y diástole, similares a los movimientos del corazón.

Lo interesante es que Campbell introduce la conciencia de que la recuperación no es literal, el recuerdo es imposible. Memoria e invención son la misma cosa. El tenue horizonte de diferencias se deshace, se evapora entre una y otra. Y el narrador descubre que su intento de revivir concluye en un resultado: recrear.

A medida que se se alejan los años busco en la oscuridad de la memoria algún indicio evocador, imágenes o palabras, conmociones a las que uno era más propenso en la infancia. Lo que siento es que sólo hasta cierta edad, y ésta puede ser muy madura, vive uno con el fantasma del padre a todas horas. Después uno se lo inventa, si fue escaso, y se lo guarda en lo más hondo. Deja uno que lo habite y sigue caminando olvidándolo, como una segunda naturaleza que no hay por qué comentar con nadie. No se habla de eso.

Este rasgo es “clave” en La clave Morse y uno de los más peculiares y valiosos en un libro de por sí inusual dentro del contexto de las culturas mexicana y latinoamericana, raramente inclinadas al género de las memorias y autobiografías.

Otro rasgo concomitante es que la memoria recompone y recrea los hechos a partir de la idea de que el recuerdo puede (¿puede?) compartirse. Así, el narrador/autor busca comparar y complementar su propia memoria con las de sus hermanas Olivia y Azucena, pero en vez de revigorizar su capacidad personal de recuerdo, descubre que los recuerdos sobre la misma persona son diferentes, y que cada uno, recordando al mismo, recrea sin embargo a seres distintos. Así como Cesare Pavese señaló alguna vez que sólo recordamos lo que nos ha sido "narrado", de pronto el narrador se descubre recordando lo que tal vez nunca ocurrió. “¿Cómo entender que [mi hermana] me había hecho recordar cosas que tal vez no sucedieron y que ahora están en mí justamente por haberlas recordado?” (87-88). El relato se enriquece con dos descubrimientos: que la memoria no revive lo perdido; y que lo perdido, lejos de estar afuera, es subjetivo.

Los recuerdos de infancia tienden a evitar el plano-secuencia y son, al contrario, ramalazos de imágenes, sin un orden cronológico, sin historia. A partir de la invención de la fotografía y del cine, pensamos y recordamos en imágenes, en daguerrotipos, instantáneas y fotogramas. El narrador "recuerda” al padre de esta manera: 
Me lleva en los brazos a ver los Potros en el estadio de beisbol de la Puerta Blanca. Lo veo en la trastienda de un vecino tomándose unas cervezas Mexicali con unos amigos, sobre unos barriles. Lo veo ponerse un traje elegante que le había regalado el cónsul de México en San Diego. Me dicen que está tirado allá en el bulevar, y vamos a recogerlo un amigo mío y yo. Nos lo traemos cargando. Veo mi alcancía rota a martillazos. Descubro una botella de Cuervo en la lavadora. De atenerme a las fotografías de la memoria, esas huellas cuadradas y sin papel en que fijarse, rescataría ciertas escenas aisladas, ninguna secuencia... (18)

Escenas aisladas, ninguna secuencia. Fotografías fijas ("veo”), o fotogramas que se extienden en el tiempo, al modo del cine ("me lleva en los brazos"), cada una de esas imágenes fotográficas o planos cinematográficos no tiene relación con otras, se valen por sí mismas. En todo caso la memoria afectiva los guarda en el álbum del sentimiento.

Con la madre sucede algo diferente. A la madre le debemos el lenguaje; hay una relación más profunda y de otra naturaleza que con el padre. A partir del recuerdo de haber estado junto a la madre durante su agonía, el narrador hace otro descubrimiento. Mientras su hermana Azucena hablaba,

...yo escuchaba la voz de mi madre a lo largo de los dieciocho meses que pasé a su lado mientras agonizaba, no porque su timbre se pareciera al de Azucena sino porque la oscuridad me consentía distraerme y pensar por otro lado que hay voces internas que uno va guardando: las voces que le enseñaron a uno a hablar, a aprender una cierta lengua, a nombrar las cosas, y se quedan grabadas para siempre dándonos una primera idea del mundo, una composición de lugar. (47)

En el proceso memorioso que desarrolla este hermoso libro, Campbell introduce también el valor del lugar en la recomposición de la identidad. El lugar no implica sólo la asociación proustiana de la memoria “involuntaria” como sucede al ver Marcel las Agujas de Vinteuil (Au coté de Chez Swan, de Marcel Proust), sino que, para Campbell, el lugar, en la complejidad de sus sensaciones, produce una sensación más, ya no de búsqueda sino de encuentro:

Siempre que puedo y me encuentro en la región por motivos de trabajo me abandono sin pensarlo mucho al deseo de pasar por lo menos una noche en Navojoa. Me gusta volver sobre sus calles, entrar en el mercado y reconocer los olores del cuero y el café recién tostado. Una sensación de pertenencia me viene de mis pasos. Me sé más completo aquí que en cualquier parte del mundo. No me cabe la menor duda de que me llamo como me llamo. (37)

¿Navojoa? es el lugar materno, el vientre, el útero. La madre siempre se reencuentra, aunque el padre se pierda. (La portada del libro es una fotografía en sepia, sobre la cual se imprime el título y el nombre del autor y la editorial. En la fotografía, el padre, de pie, apoya la mano derecha sobre el hombro de su hijo, y la madre, sentada, está rodeada por los niños: dos hijas y un hijo, los cuales sostienen un listón que los une. Es la foto “tradicional” de la familia, sólo que en esta hay un punctum — según lo denomina Roland 
Barthes en Camara obscura - forzado por el truco de la superposición digital: en su otra mano el padre sostiene unas tijeras de hojas largas. Las tijeras con que alguna vez cortará el listón que une a la familia. Lo insólito es que la fotografía no es de la familia de Campbell, y fue decidida por el caratulista sin el consentimiento del autor. ${ }^{4}$ Este hecho funda un equívoco, una ambigüedad, que se corresponde de todos modos a la naturaleza misma del libro: recuerdo que es ficción, ficción que es memoria.

En la marginalia de este libro (las entrevistas al autor y los artículos del mismo) puede encontrarse explícita otra figura del "padre" —el padre literario. La figura es aquí doble. Federico Campbell se ha referido a Juan Rulfo y a Leonardo Sciacia, una y otra vez, como figuras claves en la escritura de La clave Morse. "[Rulfo y Sciascia] han sido mis padres literarios. Uno se inventa al padre cuando fue escaso o ya no lo tiene. Yo fui en busca de un padre tierno y ético en Sicilia. Luego Rulfo se me perdió en el silencio de Insurgentes Sur como Fernando Jordán en la Baja California. Tanto Sciascia como Rulfo tienen un estilo telegráfico. Habitan un campo lacónico de la literatura. Decir lo más con el mínimo de palabras". ${ }^{5}$

Los padres literarios le enseñaron el estilo, mientras la madre le enseñó el lenguaje:

La que pone las palabras es la madre, porque las mujeres tienen la misión de enseñar a hablar a los hijos. Hay una femineidad en las palabras, como las que se aprenden de la amante (en otras lenguas, por ejemplo). La mejor elaboración sobre el padre y la muerte está en Juan Rulfo, en Pedro Páramo. La muerte del padre es una cosa. Otra el tema del padre alcohólico (como en Raymond Carver). Y otra más, la muerte del padre asesinado. Entre los hijos de padre asesinado se da una extraña identificación. Rulfo nunca se resignó a la muerte de su padre. Lo único que quería en esta vida era escribir un libro sobre la muerte de su padre. Cuando lo publicó, ya no tuvo necesidad de escribir nada más. ${ }^{6}$

En La clave Morse el cine está presente. En primer lugar, la referencia directa que proviene del uso metafórico del cine [“Caminaba como Henry Fonda” (76)], o los recuerdos de infancia ["Eran muchas horas las que debía esperarlo, pero enfrente estaba el Cinelandia, donde vi —a veces embelesado, a veces en pánico- La pasión de los fuertes, Las arenas de Iwo Jima, El horizonte en llamas”; “Al caer la tarde, después de bañarnos, nos metíamos en un cine al aire libre y veíamos películas de Audie Murphy y de Randolph Scott, de guerra o de vaqueros. Río Rojo, con Montgomery Cliff y John Wayne, la vi cinco veces” (32)]. En segundo lugar, la presencia del cine en el libro se establece a través de la idea misma del recuerdo como invención. Debido el carácter mitopoiético del cine - y su simultánea facultad de reordenar los usos de la mente como un instrumental del imaginario tanto de la vigilia como del sueño- la "ficción" del cine provee los recursos para establecer las secuencias del recuerdo de la vida real. Sigmund Freud denominaba “novela familiar” a la fantasía que el paciente elaboraba sobre su propio

\footnotetext{
${ }^{4}$ Aclaración de F. Campbell al autor de este artículo, en carta del 30 de octubre de 2001.

${ }^{5}$ Pilar Jiménez, "La ficción de la memoria” [entrevista con Federico Campbell], sin data, enviada por el escritor al autor de este artículo.

${ }^{6}$ Federico Campbell: "La invención de la memoria”, sin data. Remitido por el escritor al autor de este ensayo.
} 
lugar en la familia, fantasía ordenada en su mente con el modelo de una "novela”. Ahora, en vez de novela podría decirse película. De haber vivido en la segunda mitad del siglo veinte, probablemente Freud habría denominado ese mecanismo mental como la película familiar.

\section{El ABuelo CHENO - DEL OlVIDO AL NO ME ACUERDO}

La clave Morse establece su propia vinculación entre cine y literatura. Lo singular es que nosotros podemos enriquecer ese vínculo con otro, paralelo e independiente de Campbell, y que proviene del mundo de Juan Rulfo: la obra cinematográfica de Juan Carlos Rulfo. El abuelo Cheno (México 1995) ${ }^{7}$ y Del olvido al no me acuerdo (México 1999), ${ }^{8}$ forman parte de otra Telemaquia. ${ }^{9} \mathrm{Y}$ en el caso de El abuelo Cheno, implícitamente sellan el pacto literario desde el cine mismo al transformarse en una búsqueda del "abuelo" que, a su vez, explica retrospectivamente la literatura del padre.

En su tiempo pocos supieron que el cuento de Juan Rulfo, “¡Diles que no me maten!”, tenía una estrecha relación con la muerte de su padre. Aun cuando Rulfo había dejado pistas frescas: sus personajes se llaman Juvencio Nava y Guadalupe Terreros, y el del hombre que había matado a Don Cheno era una combinación de los dos: Guadalupe Nava. Sin necesitar referirse expresamente a este cuento, Juan Carlos Rulfo viaja a la tierra del abuelo buscando recomponer aquella historia en las voces múltiples, individuales y colectivas de quienes lo sobrevivieron. El documental es fascinante en muchos sentidos, uno de los cuales resulta de comprobar cómo persiste la señal de la cruz mortuoria en el lugar en que Don Cheno cayó muerto después de haber sido baleado. En lo que, sin embargo, los memorialistas a veces no coinciden es en los motivos que llevaron al acto de violencia: una mujer dice que "lo mandaron matar”, Motilón lo niega; otro señala que el asesino estaba ebrio y ya enemistado con Cheno. Si el misterio permanece más allá del acto, le permite a Juan Carlos Rulfo explorar, con su ejemplo, la fragilidad de los misterios de la memoria. ${ }^{10}$

\footnotetext{
${ }^{7}$ El abuelo Cheno y otras historias (México 1995, 30 minutos). Director: Juan Carlos Rulfo; Guión: Juan Carlos Rulfo, con textos de Juan Rulfo; Fotografía: Federico Barbabosa; Música: Gerardo Tamez; Montaje: Ramón Cervantes, Juan Carlos Rulfo; Intérpretes: Don Jesús Ramírez El Motilón, Juan Cobián, Cirilo Gallardo, Juan Gallardo, Ramón García, Mariano Michel, José Nava Palacios, Octavio Nava, Doña Esperanza Paz, Doña Consuelo Reyes, Pablo G. Zamora; Productor: María Fernanda Suarez - Gustavo Montiel Pagés- Centro de Capacitación Cinematográfica.

${ }^{8}$ Del olvido al no me acuerdo (México 1999, 70 minutos). Director: Juan Carlos Rulfo; Guión: Juan Carlos Rulfo; Fotografía: Federico Barbabosa; Música: Gerardo Tamez; Montaje: Ramón Cervantes, Juan Carlos Rulfo; Intérpretes: Justo Peralta, Rebeca Jiménez, Los Mudos, Jesús Ramírez, Juan José Arreola, Manuel Cossío, Clara Aparicio de Rulfo, Aurora Arámbula de Michel, Juan Michel, Eloísa Partida de Peralta, Cirilo Gallardo, Fausta Campos, Consuelo Reyes, Victor Parra, Don Alberto "El Triste”, Matías Rulfo, José González, Simeón Castillo, Jaime Sabines; Productor: La Media Luna Producciones - Instituto Mexicano de Cinematografía - Producciones X Marca - Fundación Juan Rulfo.

${ }^{9}$ A la cual habría que añadir otro film, no estrenado: Luvina. Juan Carlos Rulfo tomó el texto de su padre, de igual título, y elaboró un film de imágenes.

${ }^{10}$ Véase el guión, publicado junto con otros textos, en: Juan Carlos Rulfo: El abuelo Cheno y otras historias. México: Ediciones El Milagro, Instituto de Cinematografía, 1995.
} 
Este es un film sobre un lugar y sus hombres, tanto o más que sobre un asesinato (que, sin que ninguno de los habitantes lo supiera, acaso produjo al mejor narrador mexicano del siglo veinte), y sobre la violencia histórica en una región famosa por los levantamientos “cristeros” (1926-1929). El fanatismo de los campesinos que se levantaron en armas contra el gobierno central para defender las prerrogativas de la Iglesia católica, herida en esa época en sus intereses materiales, si bien resulta tema histórico, reaparece en fragmentos de la memoria. Como reaparece aun un período anterior, pre-revolucionario —la dictadura de Porfirio Díaz- entonada en una canción infantil que una mujer recuerda con portentosa memoria desde la banda de sonido.

Región profundamente conservadora y violenta, ésta de Jalisco se halla cruzada por la agitada historia mexicana y en algunos casos mantiene, aún vivos, a algunos de sus más temibles protagonistas. Es el caso de Cirilo, testimoniado por varios hombres y aceptado por él mismo. Cirilo "lleva [por lo] menos de ocho a nueve... que se ha echado al platito", como explica Motilón. En una secuencia magníficamente armada (se alternan imágenes del mismo relato de un duelo al menos tres veces narrado en diferentes escenografías), Motilón cuenta cómo Cirilo mató a otro hombre y luego le dijo al padre de la víctima: “Ahí está su hijo. Lléveselo”. En el presente de la película, Cirilo es un hombre apaciguado por su edad y con una apariencia de tanta fragilidad que el espectador, sin otra información complementaria, no sospecharía que fue un hombre violento y que mató a varios hombres cuando era joven. La película usa esa fragilidad en una larga secuencia en la que Cirilo monta a su burro con gran dificultad.

Es probable que Juan Carlos Rulfo no hubiera podido hacer esta película de no haber encontrado a estos hombres casi centenarios, como habría fracasado notablemente de no haber hallado a un verdadero "personaje” en la figura de su guía, Motilón (¿el Abundio de Juan Preciado?). ${ }^{11}$ Algo más joven que los demás, Motilón resulta único por la expresividad concisa y parca con que "filosofa” sobre vida y muerte. Como si fuera él mismo un personaje de Juan Rulfo. "Todos vivimos de recuerdos, y el recordar es vivir. Para mí es una tranquilidad, el recordar”. Analfabeto, añora la posibilidad de haber estudiado siquiera unos meses, al nivel del kinder. Recuerda cómo las mujeres no se paraban a mirarlo por lo zaparrastroso de sus vestimentas de pobre, desde los quince años. Motilón es un filósofo natural, ya sea cuando elogia el hecho de que la muerte sea igualitaria ("Es bueno que la muerte sea pareja”), como cuando parece haber aprendido que es recomendable vivir sin prisas. "Si le da uno mucha prisa, pos más pronto se lo lleva a uno la chingada", por lo cual es mejor "llevársela uno tikirisi, tikirisi [take it easy]..." E insiste: "porque si la violenta uno, pronto se lo lleva a uno Dios".

Juan Carlos Rulfo busca a su abuelo a partir del silencio del padre. Con su propia voz aterciopelada, apagada y triste, en la banda sonora, confía cómo su padre "nunca nos habló del abuelo”, y sin embargo les contaba historias que podían evocarlo. Ahora el hijo (Juan Carlos) continúa la tradición del padre (Juan) en el relato acongojado y fatalista que

${ }^{11}$ Así como, en la novela Pedro Páramo, Juan Preciado llega al pueblo conducido por un arriero (Abundio), Juan Carlos Rulfo emplea a Jesús Ramírez, alias El Motilón en el papel de su guía, orientador e informante, en El abuelo Cheno y otras historias. El mismo personaje, pero esta vez sin la referida función, reaparece en Del olvido al no me acuerdo. 
resulta, en cine, una buena representación del mundo literario de Juan Rulfo. Sin embargo, la película tiene una imponente fuerza visual antes que literaria. Desde las primeras tomas se advierte una sensibilidad hábil para integrar partículas dispares de un mundo total. Así, por ejemplo, las tomas del desierto y las lejanas montañas rocosas se emparejan a los primerísimos planos de manos humanas endurecidas por el trabajo y de rostros agrietados por el tiempo y el clima. Y los cascos ruinosos de las haciendas, destruidos por el tiempo, parecen evocar las iglesias sin techumbre de la narrativa de Rulfo. ${ }^{12}$ La corrosión del tiempo resulta, como la muerte, "pareja” tanto para los hombres como para sus obras.

Una banda de músicos lleva el relato al presente y éste es ligeramente diferente: en primeros planos de pies que bailan se presenta una realidad más joven, activa y feliz que la de los viejos testigos convocados. Es un contraste fugaz, reiterado una y otra vez pero marginal, y que en todo caso da mayor fuerza, por contraste, al grupo de ancianos.

Con El abuelo Cheno y otras historias Juan Carlos Rulfo incursionó en una modalidad muy contemporánea: la del documental subjetivo. En su origen, estas entrañables imágenes valen y se justifican por una presencia ausente a lo largo del relato: Juan Rulfo se fue muy joven de la región y no dejó su recuerdo entre los habitantes. Ninguno se refiere a él, probablemente ninguno leyó sus libros. Sin embargo, Juan Rulfo les dio vida a estos hombres a través de su literatura y Juan Carlos Rulfo los hizo vivir otra vez en la pantalla. La tarea del padre se continúa en la del hijo. Como en el ejemplo de Federico Campbell, uno es el otro; la literatura se funde con el cine.

El ejercicio de la memoria — frágil y todopoderosa a la vez - se continuaría en un segundo documental de Juan Carlos Rulfo, igualmente hermoso pero más complejo: Del olvido al no me acuerdo.

Medio siglo atrás, veíamos e imaginábamos a México a través de la fotografía de Gabriel Figueroa. ${ }^{13}$ El gran embajador nacional que es el cine proyectó un México rural de héroes populares con grandes sombreros y bravías mujeres que los seguían a pie - las soldaderas de Enamorada (Emilio Fernández, México 1946)—, pero, ante todo, aquellos paisajes majestuosos de nubes pesadas en el horizonte y cactus perfilados en el contraste de luz del atardecer. Por el contrario, en la espléndida Del olvido al no me acuerdo, Juan Carlos Rulfo "habla” con la película misma sobre la transitoriedad, la fugacidad, la pérdida, y así como Figueroa construía una sólida consistencia de la realidad mexicana, Rulfo despedaza esas mismas nubes de gran angular, magníficas, y las desplaza por el cielo con velocidad insólita. Para Juan Carlos Rulfo el cielo parece haber tomado el lugar del río para Heráclito. El leit-motif es el cielo nublado de las más diversas formas pero siempre activo, moviéndose ligero y desapareciendo sin irse del todo.

\footnotetext{
${ }^{12}$ Además de escritor, Juan Rulfo demostró ser un notable fotógrafo, que registra con su cámara el mundo derruido y desolado de su narrativa y, sin embargo, mantuvo durante décadas dicha actividad en secreto. Finalmente algunas ediciones de sus fotografías dan cuenta de su inmenso talento visual. La edición más reciente de sus fotografías es: México: Juan Rulfo fotógrafo. Barcelona/Madrid: Lunwerg, 2001 [Exposición Espai Xavier Miserachs - Palau de la Virreina, Barcelona, 20 abril-2 septiembre 2001].

${ }^{13}$ Notables stills de Figueroa se pueden apreciar en el libro-homenaje Gabriel Figueroa: la mirada en el centro. Cuestiones de su estética pueden verse en un libro excelente de Alberto Isaac: Conversaciones con Gabriel Figueroa.
} 
La película de Rulfo habla de la fugacidad a partir de la pérdida del padre. Así como la literatura de su padre partió de otra orfandad ["Es algo difícil crecer sabiendo que la cosa de donde podemos agarrarnos para enraizar está muerta” (“Diles que no me maten!” 58)], el hijo busca al padre convocándolo oblicua, indirectamente. Por eso no hay imágenes directas — fotografías - de Juan Rulfo. Como a Pedro Páramo, hay que reconstruirlo a partir de los relatos. En gran medida, a través de la madre, quien interviene en la película desandando su propia vida para ir al encuentro de un “Juan” juvenil, tímido, enamorado y, más tarde, en una de las emotivas secuencias finales, para hablarle a aquel Juan desaparecido y expresarle el deseo (que es una afirmación de vida) de realizar el mismo recorrido, si hubiese sido posible vivir por segunda vez. Aunque en cine no hay antecedentes de una Telemaquia realizada a través de la madre (al contrario, Telémaco se apartó de ella para buscar a Ulises), que ella tenga esa característica subraya la motivación profunda de la búsqueda, diferente - $-\mathrm{y}$ tal vez hasta opuesta - a una investigación periodística o a un documental convencional sobre un escritor famoso.

No, la búsqueda que Juan Carlos emprende de su padre Juan no busca ese tipo de precisiones: él lo vio, lo tocó, lo olió, creció a su lado. Su búsqueda tiene la forma de un ritual de la memoria. El gran tema de la literatura de Rulfo fue esa tensión creativa entre el recuerdo y el olvido. En todos sus textos los narradores y los personajes recuerdan y olvidan en igual medida. Acaso recuerdan lo que han olvidado y olvidan (al recrear y deformar con la fragilidad de la memoria) los recuerdos profundos. Así, la película teje su relato sobre la imprecisión, ya sea cuando Clara Aparicio de Rulfo se siente frustrada porque no recuerda una calle, como cuando Juan José Arreola confiesa no recordar en cuál de dos construcciones (él está ante ellas) Rulfo le había “confesado” haber nacido.

“Tratándose de Juan, todo se convierte en leyenda”, dice Arreola. Un momento importante de la leyenda —o del mito — reaparece en la película cuando Clara narra un sueño y el diálogo subsiguiente con una amiga. Ella había soñado que volvía a casarse con Juan y ambos estaban en la iglesia. Pero Juan no tenía zapatos y ella tampoco podía verle la cara. Su amiga le dijo: "Con el que te casaste... nunca existió. No te casaste con nadie” - lo cual a su vez recrea las imágenes de una Comala vacía en que aparecen fantasmas de mujeres y murmullos untados a las paredes. La realidad del mundo es tan fantasmal como la del trasmundo. Aunque ella tiene su sitio, Juan Carlos no va detrás de la leyenda, como tampoco de la reconstrucción documental del padre. Con mayor sensibilidad y arte, busca a Rulfo (y lo encuentra) a través de la región, el paisaje, las gentes, el desierto, las nubes que corren en el cielo.

Por eso, la historia “de amor” de Clara y Juan (que en el ámbito escrito se recrea a través de las cartas de Juan Rulfo publicadas por su esposa: Aire de las colinas), en vez de ser "única” y específica, aparece en esta película entrelazada con otras "historias de amor”, de diferentes parejas de viejos y ancianos que han podido sobrevivir juntos y, de diversas maneras conmovedoras (incluyendo la del silencio), las testimonian y expresan frente a la cámara. Aunque es obvio que son convocados por ella (la cámara) y de alguna manera "actúan" su vida, resulta extraordinario contemplar y escuchar ese "amor de viejos” que, antes de serlo, fue un amor de jóvenes. Notablemente, esas vidas conjuntas, que debieron ser difíciles por lo extendidas en el tiempo, contienen chispazos vitales captados en canciones, versos y bailes de pareja, así como también situaciones insólitas 
(por ejemplo, la de un marido que parece no hablarle a su mujer, a su lado, desde hace años).

Lo que consigue Juan Carlos Rulfo con estos personajes (como lo había hecho en El abuelo Cheno) no es mostrar lo "exótico" de una región pobre y de vidas extenuadas, donde el desierto y las grietas del suelo parecen extenderse a los rostros curtidos de hombres y mujeres. Rulfo sabe o intuye que el cine es rostro, es semblante, es fisonomía, pero lejos del ademán realista no le tiene miedo a acercar esos rostros a la cámara (no la cámara a los rostros) y deformarlos ópticamente, de una manera estética y estilísticamente consistente. Otra vez la comparación y la diferencia con el gran Figueroa: en el cine de Rulfo no se busca el hiperrealismo sino una realidad en que la imagen juega un papel central, como en el surrealismo. De ahí ese desierto interminable con dos sillas. De ahí las nubes que huyen tanto natural como artificialmente (por la "magia” del cine).

Nadie se equivoque. La presencia de iglesias es comparable a la ausencia de sacerdotes. No hay aquí una mística, ni una religión. Hay en cambio la certeza de la muerte y del olvido. No por casualidad la película concluye con uno de esos increíbles personajes de Jalisco y de (Juan y Juan Carlos) Rulfo, un viejo que filosofa delante de su milpa, con sagacidad incuestionable, haciendo una síntesis de su vida:

Tan bonito es este mundo porque de preciso yo creo que no hay otro igual a éste. No se cansa uno de vivir, aunque esté pobre, aunque esté enfermo, aunque esté como esté. (...) Yo fui pobre todo el tiempo, nomás que yo gasté centavos y fui parrandero (...). Pero todo se acaba, se acaba el humor, se acaba todo. Pero no hay otra vida que sea tan bonita como la primera, que es este mundo.

Este personaje expresa más el “mundo” literario de Juan Rulfo que mil artículos y libros sobre el escritor. Haberlo encontrado y articulado como imagen, así como a los muchos otros que habitan esta película, es el triunfo del cineasta.

Escribe Federico Campbell en su ensayo titulado "La invención de la memoria”:

Rulfo era la literatura misma. Nació sabiendo que no tenía sentido revelar una realidad ya establecida sino recrearla a partir de la imaginación, la memoria, la experiencia y la emoción. En Pedro Páramo está toda su vida (la muerte de su padre, la atmósfera de San Gabriel y Tuxcacuesco, el papalote con que jugaba, el viento), no de manera autobiográfica, pero allí está el desenvolvimiento de los pliegues de su memoria que —en conjuntos, categorías, mapas, clasificaciones- permiten que comparezcan los sonidos de la lluvia, el calor de Comala, las estrellas y el volcán de Colima que contemplaba desde la azotea de su casa cuando era niño. ${ }^{14}$

Federico Campbell y Juan Carlos Rulfo buscan al padre, se revelan Telémacos latinoamericanos. Uno se inspira en Juan Rulfo, el otro busca a Juan Rulfo. Los caminos de la literatura y del cine tienen extrañas maneras de intercomunicarse, de abrazarse. En estos ejemplos se realizan las fecundas nupcias de dos órdenes artísticos distintos del

\footnotetext{
${ }^{14}$ Federico Campbell: “La invención de la memoria”, sin data. Remitido por el escritor al autor de este ensayo.
} 
imaginario. ¿Buscando certezas? ¿Explorando la identidad a partir de la pérdida? ¿Respondiendo a la ansiedad del milenio? Estas preguntas pierden instantáneamente los signos de interrogación y se convierten en afirmaciones. Las obras transforman a las preguntas en sus propias respuestas. ${ }^{15}$

\section{BiBLIOGRAFÍA}

FILMS:

Bajo California (Carlos Bolado, México 1998).

Central do Brasil (Walter Salles, Brasil 1997).

Cuestión de fe (Marcos Loayza, Bolivia 1995).

Danzón (María Novaro, México1991).

De la calle (Gerardo Tort, México 2001).

Del olvido al no me acuerdo (Juan Carlos Rulfo, México 1999).

El abuelo Cheno (Juan Carlos Rulfo, México 1995).

El camino (Javier Olivera, Argentina 2000).

El misterio de los ojos escarlata (Alfredo J. Anzola, Venezuela 1993).

El viaje (Fernando Solanas, Argentina 1992).

Enamorada (Emilio Fernández, México 1946).

Esperando al Mesías (Daniel Burman, Argentina 2000).

Imagen latente (Pablo Perelman, Chile 1987).

Invierno, mala vida (Gregorio Cramer, Argentina 1997).

La conquista del paraíso (Eliseo Subiela, Argentina).

La estación del regreso (Leonardo Kocking, Chile 1987) .

La línea paterna (José Buil - Marisa Systach, México 1994).

La película del Rey (Carlos Sorín, Argentina 1985).

La Tierra del Fuego se apaga (Emilio Fernández, Argentina, 1955).

Luvina (Juan Carlos Rulfo, México, s.d.).

Martín hache (Adolfo Aristarain, Argentina 1997).

Mi hijo el Che (Fernando Birri, Argentina 1985).

Pequeños milagros (Eliseo Subiela, Argentina 1997).

Picado fino (Esteban Sapir 1996).

Por la libre (Juan Carlos De Llaca, México 2000).

¿Quién diablos es Juliette? (Carlos Marcovich, México 1997).

Santitos (Alejandro Springall, México 1999).

Terra estrangeira (Walter Salles y Daniela Thomas, Brasil 1995).

Un crisantemo estalla en cinco esquinas (Daniel Burman, Argentina 1996).

\footnotetext{
${ }^{15} \mathrm{Al}$ interior del cine mismo, en los noventa la búsqueda del padre ha dado resultados extraordinarios en documentales como el mexicano La línea paterna (José Buil - Marisa Systach, México 1994) y el venezolano El misterio de los ojos escarlata (Alfredo J. Anzola, Venezuela 1993), reescrituras fílmicas de la creatividad del Padre como Cineasta. Un ejemplo cronológicamente anterior, más reducido pero significativo del Padre como Cineasta es lo que filmó Roberto Guevara de su hijo Ernesto cuando niño (incorporado a Mi hijo el Che, Fernando Birri, Argentina 1985).
} 
LiBRos:

Burman, Daniel. Entrevista. "Esperando al Mesías, una película argentina sobre la identidad y los judíos”. Zero-Variedades 347 (25 de noviembre de 2000).

Campbell, Federico. De cuerpo entero. México: UNAM/Corunda, 1990.

La clave Morse. México: Alfaguara, 2001.

"La invención de la memoria”. s/d.

"La ficción de la memoria”. Entrevista con Pilar Jiménez. s/d.

Carneiro, João Emanuel, Marcos Bernstein y Walter Salles. Central do Brasil. [guión] Rio de Janeiro: Editorial Objetiva, 1998.

Gabriel Figueroa. la mirada en el centro. Presentación de Pedro Joaquín Coldwell y prólogo de Carlos Monsiváis. México: Grupo Editorial Miguel Angel Porrúa, 1993.

Isaac, Alberto. Conversaciones con Gabriel Figueroa. Guadalajara: Universidad de Guadalajara, 1993.

México: Juan Rulfo fotógrafo. Barcelona/Madrid: Lunwerg, 2001.

Parisi, Lida y Abel González. La fin del mundo. Buenos Aires: Centro Editor de América Latina, 1971.

Rulfo, Juan Carlos. El abuelo Cheno y otras historias. México: Ediciones El Milagro, Instituto de Cinematografía, 1995.

Rulfo, Juan. Aires de las colinas. Cartas a Clara. México: Areté, 2000.

Rulfo, Juan. “Diles que no me maten!”. Obra completa. Jorge Ruffinelli, ed. Caracas: Biblioteca Ayacucho, 1977.

Rulfo, Juan. Pedro Páramo. Obra completa. Jorge Ruffinelli, ed. Caracas: Biblioteca Ayacucho, 1977.

Thomas, Daniela, Walter Salles y Marcos Bernstein. Terra estrangeira. [guión] Rio de Janeiro, 1996. 